\title{
A novel 5-fluorouracil-resistant human esophageal squamous cell carcinoma cell line Eca-109/5-FU with significant drug resistance-related characteristics
}

\author{
CHI ZHANG ${ }^{1 *}$, QUNFENG MA $^{2 *}$, YINAN SHI $^{1}$, XUE LI $^{1}$, MING WANG $^{1}$, JUNFENG WANG $^{1}$, \\ JIANLIN GE ${ }^{1}$, ZHINAN CHEN ${ }^{3}$, ZILING WANG ${ }^{1}$ and HONG JIANG ${ }^{1}$
}

\begin{abstract}
${ }^{1}$ College of Life Science and Bioengineering, School of Science, Beijing Jiaotong University, Haidian, Beijing 100044; ${ }^{2}$ Department of Thoracic Surgery, Affiliated Hospital of the Academy of Military Medical Sciences, Fengtai, Beijing 100071; ${ }^{3}$ Cell Engineering Research Center, The Fourth Military Medical University, Xicheng, Xi'an, Shaanxi 710032, P.R. China
\end{abstract}

Received September 1, 2016; Accepted October 31, 2016

DOI: $10.3892 /$ or.2017.5539

\begin{abstract}
Fluorouracil (5-FU) is used for the clinical treatment of esophageal squamous cell carcinomas (ESCCs), yet it also induces chemoresistant cancer cells during treatment, which leads to the failure of the therapy. To further explore the resistance mechanism of 5-FU in ESCC, we established the 5-FU-resistant ESCC cell line Eca-109/5-FU, which was prepared by the stepwise exposure to increasing 5-FU concentrations. MTT assay and nude mouse xenograft models were used to test the drug resistance and proliferation of Eca-109 and Eca-109/5-FU cells in vitro and in vivo. Apoptosis and cell cycle distribution were determined using flow cytometry. Drug resistance-related proteins were detected by western blotting. Metabolomic profiles were obtained from nuclear magnetic resonance (NMR) tests. In regards to Eca-109/5-FU, the decreased susceptibility to 5-FU was determined in vitro and in vivo with slower rate of proliferation. Drug resistancerelated proteins (multidrug resistance-associated protein 1 and ATP-binding cassette superfamily G member 2), epithelial-tomesenchymal transition (EMT)-related proteins (E-cadherin and vimentin) and cancer stem cell-related proteins (prominin-1 and hyaluronate receptor) exhibited significant differences between the two cell lines. The 5-FU-resistant cell line Eca-109/5-FU achieved the ability to tolerate 5-FU, which may depend on significant drug resistance-related characteristics, such as EMT and cancer stem cell-like properties. The metabolism of Eca-109/5-FU was altered, and more than 15 metabolites was found to contribute to the difference in the
\end{abstract}

Correspondence to: Dr Hong Jiang, College of Life Science and Bioengineering, School of Science, Beijing Jiaotong University, 3 Shangyuancun, Haidian, Beijing 100044, P.R. China

E-mail: jhong@bjtu.edu.cn

${ }^{*}$ Contributed equally

Key words: esophageal squamous cell carcinoma, 5-fluorouracil, CDDP, Eca-109, chemoresistance metabolite profile, such as lactate, glutamate, taurine, glutamine, proline, aspartate, methanol, cystine, glycine and uracil. Our results identified that the resistant cell line Eca-109/5-FU showed quite different characteristics compared with the parental Eca-109 cells. The Eca-109/5-FU cell line provides an experimental model for further steps to select chemotherapeutic sensitizers.

\section{Introduction}

The morbidity of esophageal carcinoma (EC) ranks eighth among malignant tumors globally, and is the sixth leading cause of cancer-related death. According to statistical studies, there were $\sim 455,800$ new cases worldwide, with 400,200 deaths in 2012. Eastern Asia, particularly the North Central region of China, is a high-risk area (1). Most ECs in China are esophageal squamous cell carcinoma (ESCC), which account for $90 \%$ of all cases of EC worldwide. ESCC is different from adenocarcinoma, which is prevalent in Western countries and presents different pathogenesis, epidemiology, tumor biology and prognosis (2). ESCC has a high degree of malignancy. Despite advances in surgical therapy for ESCC, most patients have locally advanced or disseminated disease at diagnosis (3). To treat this unresectable disease, chemotherapy alone or in combination with other antineoplastic agents may be an optimal choice.

5-Fluorouracil (5-FU) is the inhibitor of thymidylate synthetase (TS), which catalyzes the rate-limiting step in DNA synthesis. Therefore, 5-FU decreases the biosynthesis of pyrimidine nucleotides (4). However, 5 -FU can be misincorporated into RNA and then inhibit RNA synthesis (5). 5-FU is used to treat many types of malignant tumors, including ESSC. The combination of 5-FU and cisplatin (CDDP) is a successful therapeutic strategy (6). However, the success of chemotherapy depends on the sensitivity of the tumor to chemotherapeutic drugs, such as 5-FU. During treatment, ESCC cells often acquire resistance to drugs and turn into chemoresistant cancer cells (CCCs), which leads to the failure of therapy. There are currently 4 known mechanisms of 5-FU resistance. The first involves intracellular changes in 5-FU metabolism, including 
anabolic and catabolic processes. To exert its cytotoxicity, the anabolic processes of 5-FU take part in nucleic acid synthesis by combining with intracellular-related enzymes, such as orotate phosphoribosyltransferase (OPRT) and uridine phosphorylase (UP). The downregulation of OPRT and UP contributes to the 5-FU resistance of cancer cells (7). However, $5-\mathrm{FU}$ is degraded by dihydropyrimidine dehydrogenase (DPD) to its nontoxic metabolites, which include $\alpha$-fluoro- $\beta$ ureido-propionic acid (FUPA), in the catabolism of 5-FU. The upregulation of DPD also contributes to 5-FU resistance (8). Thus, tumor cells became resistant to $5-\mathrm{FU}$ by inhibiting anabolic processes and activating catabolic processes. In addition, since TS is the main cellular target of 5-FU (9), increased TS activity is detected in 5-FU-resistant cancer cells (10). Second, drug-resistant cells decrease the cellular concentration of the chemotherapeutic drug and reduce its effectiveness via the activation and overexpression of drug efflux pathways. ATP-binding cassette (ABC) transporters are plasma membrane-associated and energy-dependent efflux pumps, including multidrug resistance 1 (MDR1) (11), multidrug resistance-associated protein 1 (MRP1) (12), and ATP-binding cassette superfamily G member 2 (ABCG2) (13). Their upregulation helps cancer cells to enhance cell survival against drugs and resist the cytotoxic effects of anticancer agents. Third, epithelial-to-mesenchymal transition (EMT) is closely related to chemoresistance (14). EMT is initially observed in embryonic development, in which cells lose epithelial characteristics and gain mesenchymal properties to increase motility and invasiveness (15). The molecular characteristics of EMT include the downregulation of cell adhesion molecules (E-cadherin) and the upregulation of vimentin. EMT is important in tumor progression, metastasis and chemoresistance (15) and is induced by various growth factors, such as transforming growth factor- $\beta$, hepatocyte and epidermal growth factor (16). Fourth, chemoresistant cancer cells (CCCs) may be derived from cancer stem cells (CSCs). CSCs are a non-differentiated subset of cancer cells isolated from several different tumors and characterized by an intrinsic resistance to apoptosis as well as by unusual phenotypic plasticity (17). When environmental condition became unfavorable (such as adding antitumor drugs) for cells, drug-resistant stem-like cells may originate from other cancer cells (18). The characteristics of stem cells facilitate the resistance to injury from anticancer agents and result in drug resistance. Several molecular markers are related to cancer stem-cell subpopulations, such as prominin-1 (CD133), hyaluronate receptor (CD44) and aldehyde dehydrogenase 1 A1 (19). The upregulation of CD133 and CD44 was recently detected in 5-FU-resistant gastric cancer cells (20), but has not been reported in 5-FU-resistant ESCC cells. Notably, EMT is considered a key process for CSC generation (21). The presence of CCCs is often associated with poor prognosis (22).

Overcoming drug resistance is a large issue in cancer treatment. Drug-resistant cell lines established in vitro could be useful tools to simulate the process of cell resistance, illuminate resistance mechanisms and provide a research model to select sensitizers to chemotherapy. Many 5-FU-resistant cancer cells have been established, including mucoepidermoid carcinoma (12), gastric (20) and colorectal cancer (23), hepatocellular (24) and oral squamous cell carcinoma (25), and human endometrial adenocarcinoma cell lines (26). As for ESCC 5-FU-resistant cells, TE-5 (8), TE-11 (27), KYSE410 (28) and KYSE150 (29) have been reported, and their drug resistance mechanisms have also been studied. Compared with tumor parental cells, 5-FU-resistant ESCC cells were found to exhibit upregulation of DPD (8) and PI3K/AKT (29), specific miRNA signatures (30), and the activation of Id1-E2F1-IGF2/ TS (28). To overcome resistance to 5-FU, researchers have demonstrated that photodynamic therapy (PDT) could induce potent cytotoxicity in 5-FU-resistant ESCC cells (TE-5R and TE-11R) independent of their differentiation grade or 5-FU resistance (27). In addition, upregulation of miR-148a attenuated resistance in chemotherapy-resistant variants, including 5-FU-resistant cells (31).

Despite these developments, there are still some unclear questions concerning 5-FU-resistant ESCC cells. First, the establishment of 5-FU-resistant sublines and determination of their mechanism of resistance have only been reported in 2 ESCC cell lines (KYSE and TE). Since Eca-109 was found to be more sensitive to antitumor drugs (both CDDP and paclitaxel) than KYSE cells (32), it may be easier to choose a chemotherapy sensitizer in the use of 5-FU-resistant Eca-109/5-FU cells. However, are the ABC transporters highly expressed in 5-FU-resistant ESCC cells? Sasada et al (33) explored the metabolomics of 5-FU-resistant gastric cancer cells, in which the metabolite profile is different from that of parental cells.

To further explore the ESSC resistance mechanism for 5-FU, we established a 5-FU-resistant ESCC cell line Eca-109/5-FU, which was prepared by stepwise exposure to increasing 5-FU concentrations. As for Eca-109/5-FU, the decreased susceptibility to 5-FU and lower proliferation were determined in vitro and in vivo. Drug resistance-related, EMT-related and CSC-related proteins were significantly highly expressed. These results provide an experimental model for further steps in selecting chemotherapy sensitizers.

\section{Materials and methods}

Reagents. The chemotherapeutic drugs CDDP and 5-FU were purchased from Sigma-Aldrich Chemical Co. (St. Louis, MO, USA). The anti-MRP1 (BA0567), E-cadherin (PB0583), vimentin (BM0135), CD133 (BA3992) and CD144 (PB0287) antibodies were purchased from Boster Biological Technology Ltd. (Wuhan, China). The anti-ABCG2 (RLT0053) antibody was purchased from Ruiying Bio (Suzhou, China). The anti- $\beta$-actin (BE0021) antibody was purchased from BioEasy Technology Co. Ltd. (Beijing, China). The antiproliferating cell nuclear antigen (PCNA) (ZM-0213) and secondary antibodies were purchased from Zhongshan Golden Bridge Biotechnology (Beijing, China).

Cell culture. The ESCC cell line Eca-109 was kindly provided by Dr XiaoFei Zheng of the Beijing Institute of Radiation Medicine. Eca-109 was checked by short tandem repeat (STR) analysis at the Beijing Microread Gene Technology (Beijing, China) and maintained in Dulbecco's modified Eagle's medium (DMEM) supplemented with $10 \%$ fetal bovine serum (FBS), $100 \mu \mathrm{g} / \mathrm{ml}$ penicillin/streptomycin, $2 \mathrm{mmol} / \mathrm{l} \mathrm{L}$-glutamine and HEPES buffer. 
Establishment of the 5-FU-resistant cell line Eca-109/5-FU. The resistant cell line was established in vitro by intermittent exposure of human Eca-109 to different concentrations of 5-FU in stepwise increments of time. Starting with a concentration of $0.1 \mu \mathrm{g} / \mathrm{ml}, 5-\mathrm{FU}$ was added to the cells when they grew to $70-80 \%$ confluence. When the majority of cells began to die, the remaining cells were then washed 3 times with phosphate-buffered saline (PBS) and cultured in 5-FU-free growth medium. The dead cells were washed out with PBS and fresh medium was added daily. After incubating for a few days at $37^{\circ} \mathrm{C}$ in a humidified air atmosphere containing $5 \%$ $\mathrm{CO}_{2}$, the surviving cells were restored to exponential growth without pressure from 5-FU, and the next concentration of 5-FU was then added. The drug concentration was increased to $0.2,0.4$ and $1 \mu \mathrm{g} / \mathrm{ml}$, and the maximal concentration was used 6 times until cells could live in a 5-FU maximal concentration for $>4$ days. The 5-FU-resistant cell line Eca-109/5-FU was established 12 months after the treatment was initiated, and the resistant phenotype was developed. The resistant cells were frozen in liquid nitrogen. Freeze-stored cells were recovered after 3 passages and were subjected to the identification of biological characteristics via the following experiments.

Cell viability assay. Cell viability was assessed by MTT assay. Cells were seeded in 96-well plates (5,000 cells/well) for $24 \mathrm{~h}$ at $37^{\circ} \mathrm{C}$ and treated with $5-\mathrm{FU}$ at different final concentrations $(0,0.31,0.625,1.25,2.5,5,10,20,40$ and $80 \mu \mathrm{g} / \mathrm{ml})$. Four days after treatment, the medium was removed and $5 \mathrm{mg} / \mathrm{ml}$ MTT was added to each well. The cells were maintained at $37^{\circ} \mathrm{C}$ for $4 \mathrm{~h}$; then, $150 \mu \mathrm{l}$ of dimethyl sulfoxide (DMSO) was added to each well and mixed thoroughly. The absorbance was read on a Bio-Rad microplate reader Model 550 at $490 \mathrm{~nm}$. The MTT absorbance of the untreated control cells was set to 1 to calculate the relative number of viable cells. The experiments were repeated at least 3 times to ensure reproducibility and statistical significance.

Apoptosis assay. Cell apoptosis was detected via the Annexin V binding assay and flow cytometry (FCM). Cells (Eca-109 and Eca-109/5-FU) were seeded at $1 \times 10^{5}$ cells/well in 6-well plates and treated with 5-FU at different final concentrations $(0,2.5$, $5,10,20$ and $40 \mu \mathrm{g} / \mathrm{ml}$ ) the following day. On day 4 after treatment, the cells were stained with FITC-labeled Annexin V and propidium iodide (PI) according to the manufacturer's instructions (KGA105-50, Annexin V-FITC apoptosis detection kit; Nanjing KeyGen Biotech, Nanjing, China) and FCM was performed immediately after staining. For the xenograft tumor tissue, the apoptosis of a section was analyzed by terminal deoxynucleotidyl transferase-mediated dUTP nick-end labeling (TUNEL) staining using the DeadEnd ${ }^{\mathrm{TM}}$ Colorimetric TUNEL system (G7130, Promega Corporation, Beijing, China) following the manufacturer's protocol. Hematoxylin was applied as a counterstain. In each sample, the number of apoptotic tumor cells from 50 different fields was evaluated at high magnification (x200).

Growth curves. Cell viability was assessed by MTT assay. Cells were seeded in 96-well plates (2,000 cells/well) with $0.2 \mathrm{ml}$ of medium at $37^{\circ} \mathrm{C}$ in an incubator with a humidified air atmosphere containing $5 \% \mathrm{CO}_{2}$. We detected the MTT absorbance every $24 \mathrm{~h}$ for 9 days as described above. At the same time, cells were seeded in a 96-well plate with different cell numbers (doubling the dilution from $1 \times 10^{5}$ to 200 cells/well). When they adhered to the plates after $4 \mathrm{~h}$, the MTT assay was performed, the standard curve was drawn (x-axis indicates the OD value; $y$-axis indicates the cell number) and empirical formulas were determined.

Eca-109: $\quad \mathrm{y}=0.1289 \mathrm{x}^{2}+0.0317 \mathrm{x}+0.0032, \mathrm{R}^{2}=0.9999$

Eca-109/5-FU: $y=0.1414 x^{2}+0.0317 x+0.0027, R^{2}=1$

The experiments were repeated at least 3 times to ensure reproducibility and statistical significance.

Cell cycle distribution. Cells were harvested during the exponential growth phase following trypsinization without ethylenediaminetetraacetic acid (EDTA). The cells were washed with cold PBS and fixed by suspending the cells in $1 \mathrm{ml}$ stationary liquid (30\% PBS and $70 \%$ ethanol) at $-20^{\circ} \mathrm{C}$. After 3 days, the fixed cells were washed and resuspended in $300 \mu \mathrm{l} \mathrm{PI}(50 \mu \mathrm{g} / \mathrm{ml})$ and $10 \mu \mathrm{l} \mathrm{RNase} \mathrm{A}(10 \mathrm{mg} / \mathrm{ml})$. Then, the samples were incubated at $37^{\circ} \mathrm{C}$ for $30 \mathrm{~min}$ in the darkness and the DNA content was analyzed by FCM.

Metabolic analysis. Metabolomic profiles were obtained to assess the relative distribution of various cellular metabolites of Eca-109 and Eca-109/5-FU cells. Cells were collected at $0.5 \mathrm{~g}$ wet weight and quickly frozen in liquid $\mathrm{N}_{2}$. Further study was performed by Anachro Technologies Inc. (Wuhan, China) using their described methods $(34,35)$, including sample preparation, metabolic profiling, peak identification, curation and date analysis.

Western blotting. Cell lysates were treated with RIPA lysis buffer and the protein concentrations were determined using Pierce BCA protein assay kit (Thermo Scientific, Waltham, MA, USA). Total protein (20-50 $\mu \mathrm{g})$ was separated by $15 \%$ SDS-PAGE and transferred to a nitrocellulose membrane. After incubation in 5\% non-fat milk solution, the membranes were incubated in each of the following antibodies: MRP1 (1:100), ABCG2 (1:1,000), CD133 (1:200), CD44 (1:500), vimentin $(1: 200)$, E-cadherin $(1: 500)$ and $\beta$-actin $(1: 1,000)$ at $4^{\circ} \mathrm{C}$ overnight. The proteins were visualized on Kodak X-ray film (Kodak, Rochester, NY, USA) by the application of the enhanced chemiluminescence western blotting detection system (Thermo Scientific).

Evaluation of tumor growth in vivo. The effect of 5-FU on the proliferation of Eca-109 and Eca-109/5-FU cells in vivo was investigated by xenograft tumors in nude mice as previously described (36). All applicable international, national and/or institutional guidelines for the care and use of animals were followed. All procedures performed in studies involving animals were in accordance with ethical standards of the Center of Biomedical Analysis of Tsinghua University, where the studies were conducted. First, the therapeutic dose of 5 -FU was tested by i.p. injection of 8 and $25 \mathrm{mg} / \mathrm{kg}$ body weight. The Eca-109-derived tumors in athymic BALB/c female nude mice were induced by injecting s.c. $5 \times 10^{6}$ cells resuspended in $200 \mu 1$ sterile PBS into the lower right flank of 
each mouse. Each group consisted of 3 animals, drugs were administered every 3 days for a total of 28 days, and tumor growth was monitored for 30 days. Tumor length and width were measured using a Vernier caliper every other day without knowledge of the treatment groups, and the tumor volume was calculated by 'length $\mathrm{x}$ width ${ }^{2} / 2$ '. Then, the therapeutic effects of 5-FU on Eca-109-induced and Eca-109/5-FU-induced tumors were evaluated. Sixteen mice received Eca-109 cells $\left(5 \times 10^{6}\right.$ cells $\left./ 200 \mu \mathrm{l}\right)$, and the same number of mice received Eca-109/5-FU cells with the same cell concentrations. When the size of tumors reached $50-100 \mathrm{~mm}^{3}$ (nearly 5 days), 16 animals (bearing Eca-109 or Eca-109/5-FU) were randomly divided into 2 groups (control and experimental group), each containing 8 mice. The animals in the control group were injected i.p. with $0.1 \mathrm{ml}$ PBS, and the animals in the experimental group were injected i.p. with $0.1 \mathrm{ml} \mathrm{5-FU}(25 \mathrm{mg} / \mathrm{kg})$. The tumor volume was monitored as described above. After 30 days, the animals were euthanized, and the tumors were analyzed by immunohistochemical staining with hematoxylin and eosin (H\&E), PCNA and TUNEL staining.

Immunohistochemical analysis. Immunohistochemical labeling was performed on $10 \%$ formalin-fixed, paraffinembedded tumor tissue cut into $4-\mu \mathrm{m}$ thick sections. After being deparaffinized in xylene and rehydrated in graded concentrations of ethanol, the sections were recovered in citrate buffer and blocked with $3 \% \mathrm{H}_{2} \mathrm{O}_{2}$ and $10 \%$ serum. The primary antibody PCNA (ZM-0213, 1:500) was added and incubated overnight at $4^{\circ} \mathrm{C}$. Then, the slides were incubated with the secondary antibody and the horseradish peroxidase-streptavidin complex reagent for $30 \mathrm{~min}$, respectively (Beijing Golden Bridge Biotechnology, Beijing, China). Immunolabeling was developed with chromogen 3,3'-diaminobenzidine tetrahydrochloride (DAB). Hematoxylin was applied as a counterstain. Tissue sections stained without the primary antibody served as negative controls. The staining of tissue sections was analyzed and quantified, and the results were interpreted in a blinded manner.

Statistical analysis. All experiments were performed at least 3 times. Statistical comparisons between groups were performed using unpaired Student's t-test with Statistical Package for the Social Sciences (SPSS) software version 15 (SPSS, Inc., Chicago, IL, USA). Values of $\mathrm{p}<0.05$ or $\mathrm{p}<0.01$ were considered to indicate statistically significant results.

\section{Results}

Decreased sensitivity of the drug-resistant cell line Eca-109/5-FU to 5-FU in vitro and in vivo. Eca-109/5-FU cells were prepared in vitro by intermittently exposing Eca-109 cells to increasing concentrations of 5-FU (0.1, $0.2,0.4$ and $1 \mu \mathrm{g} / \mathrm{ml}$ ) for 12 months. After the generation of Eca-109/5-FU, the cells were cultured in 5-FU-free growth medium for 3 passages ( $\sim 1$ week), and then frozen in liquid nitrogen. Cell viability was determined by the MTT method, and the data indicated that Eca-109/5-FU was more resistant to 5-FU than Eca-109. The $\mathrm{IC}_{50} 5$-FU values for the Eca-109 and Eca-109/5-FU cells were 10.5 and $45 \mu \mathrm{g} / \mathrm{ml}$, respectively. The resistance index ( $\mathrm{RI}, \mathrm{IC}_{50}$ of drug-resistant cells/ $\mathrm{IC}_{50}$ of parental cells) was 4.3, which means that Eca-109/5-FU was 4.3-fold more resistant to 5-FU than Eca-109 (Fig. 1A). We also determined the cell viability with CDDP, and there was almost no inhibition of Eca-109/5-FU cell viability when the concentration of CDDP was below $5 \mu \mathrm{g} / \mathrm{ml}$, which was significantly different in comparison with the parental cells (Fig. 1B). All of these results implied that Eca-109/5-FU may be a multidrugresistant cell line. To detect the 5-FU-induced apoptotic death in Eca-109/5-FU and Eca-109 cells, Annexin V-FITC and PI staining were performed, followed by FCM. The results indicated that the apoptotic proportion of Eca-109/5-FU cells was much lower than that of the Eca-109 cells when treated with $5-\mathrm{FU}$, and the difference was significant at $\mathrm{p}<0.01$. After being treated with low doses of 5-FU $(2.5$ and $5 \mu \mathrm{g} / \mathrm{ml})$, the apoptotic proportion of Eca-109 was $40 \%$, while that of Eca-109/5-FU was below $10 \%$. When the dose of 5-FU increased to $10 \mu \mathrm{g} / \mathrm{ml}$, the apoptotic proportion of Eca-109 reached $74.44 \%$, while that of Eca-109/5-FU was $16.36 \%$. When the cells were supplemented with the highest dose of 5-FU, the apoptotic proportion of Eca-109 was $94.76 \%$, but that of Eca-109/5-FU was $57.26 \%$ (Fig. 1C). Furthermore, we used nude mouse xenograft models (Eca-109-bearing and Eca-109/5-FUbearing mice) to determine whether Eca-109/5-FU was also resistant to 5-FU in vivo. When the xenograft tumors reached $50-100 \mathrm{~mm}^{3}$, mice from the experimental groups were treated with 5-FU. When analyzed 28 days later, the volume and weight of the Eca-109-induced tumors decreased, but there was no change in the volume and weight of the Eca-109/5FU-induced tumors (Fig. 1D and E). There was no significant difference in the tumor cell mitotic index or tissue infiltration and tumor cell proliferative index between the control groups and the experimental groups in the Eca-109-induced tumors or Eca-109/5-FU-induced tumors as determined by H\&E and PCNA staining, respectively (Fig. 1F and G). Compared with tumor tissues of the control group, a higher number of TUNELpositive stained cells was observed in the Eca-109-induced tumors treated with 5-FU, but no significant difference was found in the Eca-109/5-FU-induced tumors treated with 5-FU or PBS (Fig. 1H and I; p<0.01). These experimental results suggested that Eca-109/5-FU cells were resistant to 5-FU in vitro and in vivo.

Proliferation of Eca-109/5-FU cells was slower than Eca-109 cells in vitro and in vivo. Under a bright field of vision without 5-FU treatment, Eca-109 showed clear borders, while the borders of Eca-109/5-FU were relatively fuzzy. The cell size of Eca-109/5-FU was a bit larger than the parental Eca-109 cells. Under increasing drug concentrations, the size of Eca-109 cells gradually increased and the cell edges became indistinct, similarly to Eca-109/5-FU cells (Fig. 2A). The cell growth curve indicated that the proliferation of Eca-109 cells began to exceed that of Eca-109/5-FU at 2 days (Fig. 2B). In vivo, we established nude mouse xenograft models (Eca-109-bearing and Eca-109/5-FU-bearing mice). When the xenograft tumors reached $50-100 \mathrm{~mm}^{3}$, the volume of xenograft tumors was recorded every 3 days for a total of 28 days. The results showed that after 16 days, the proliferation of the Eca-109 cells became faster than Eca-109/5-FU, and they were significantly different at 28 days (Fig. 2C). Therefore, Eca-109/5-FU cells grew more slowly than Eca-109 cells in vitro and in vivo. To determine 

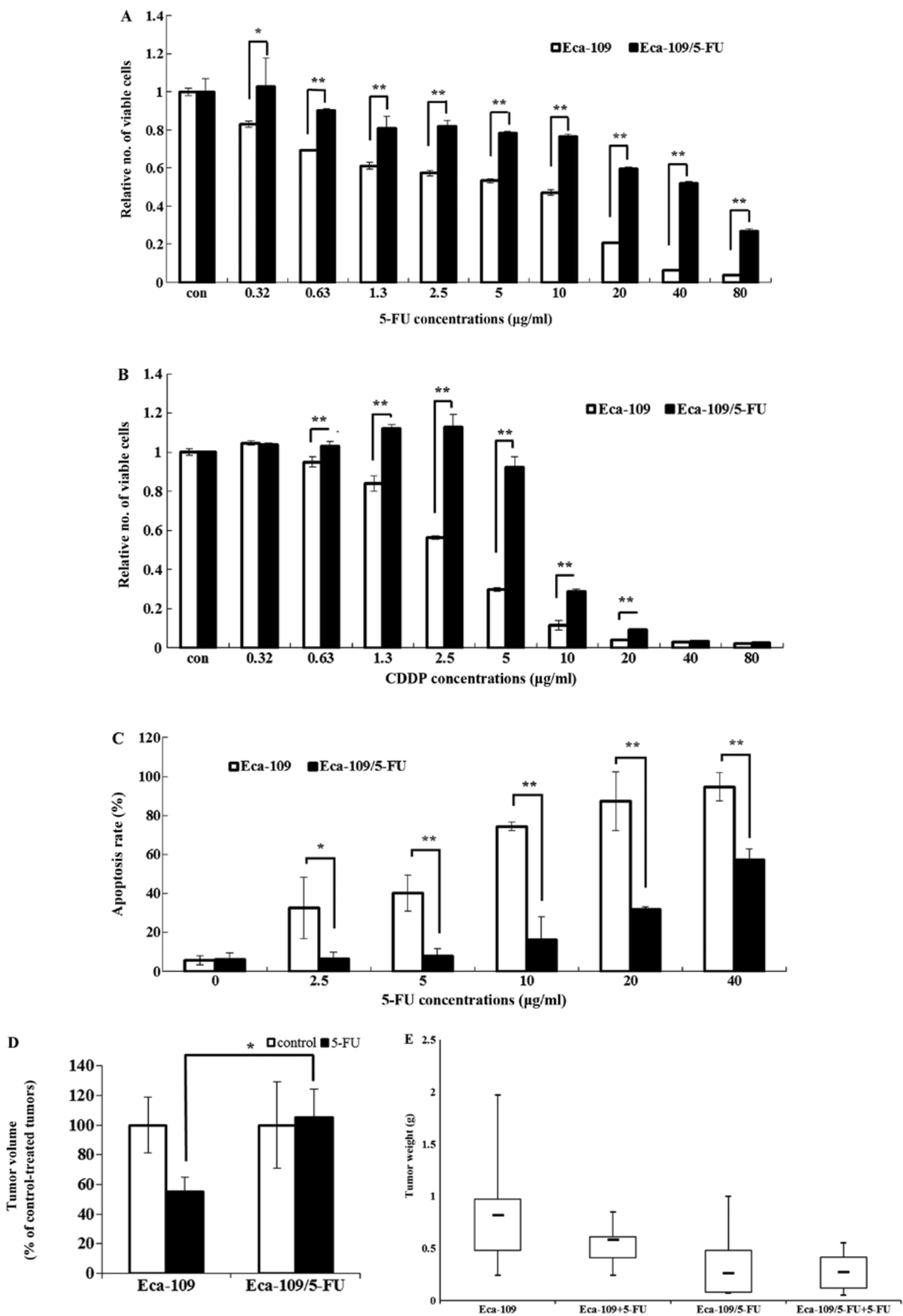

Figure 1. Eca-109/5-FU is resistant to 5-FU in vitro and in vivo. (A) The effect of 5-FU on the cell viability of Eca-109 and Eca-109/5-FU cells. Cells were treated with different concentrations of 5-FU for 4 days, and the cell viability was measured by MTT assay. Eca-109/5-FU was more resistant to 5-FU in vitro than Eca-109. (B) The effect of CDDP on cell viability of Eca-109 and Eca-109/5-FU. Cells were treated with different concentrations of CDDP for 4 days, and the cell viability was also measured by MTT assay. Eca-109/5-FU was more resistant to CDDP in vitro than Eca-109. (C) The effect of 5-FU on the apoptosis of Eca-109 and Eca-109/5-FU cells. Cells were treated with different concentrations of 5-FU for 4 days, stained with Annexin V-FITC and PI, and detected by FCM. The apoptotic proportion of Eca-109/5-FU was lower than that of Eca-109. (D) The therapeutic effects of 5-FU on the volume of Eca-109- and Eca-109/5-FU-induced tumors. 5-FU was administered every 3 days for a total of 28 days. The volume of Eca-109-induced tumors was significantly reduced, but Eca-109/5-FU-induced tumors were not significantly affected. (E) The therapeutic effects of 5-FU on the weight of Eca-109- and Eca-109/5-FU-induced tumors. The treatment of 5-FU had no significant impact on the weight of Eca-109/5-FU-induced tumors. ${ }^{*} \mathrm{p}<0.05,{ }^{* *} \mathrm{p}<0.01$. 
F 5-Fu

Eca-109/5-FU
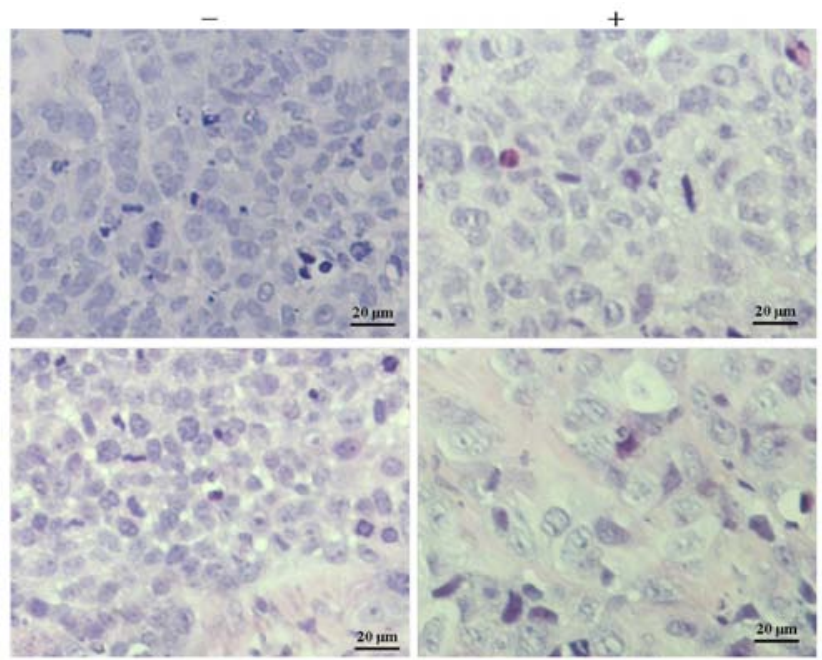

G

5-Fu

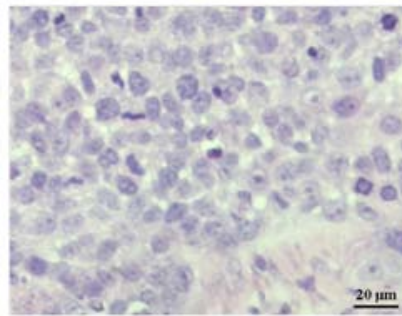

Eca-109
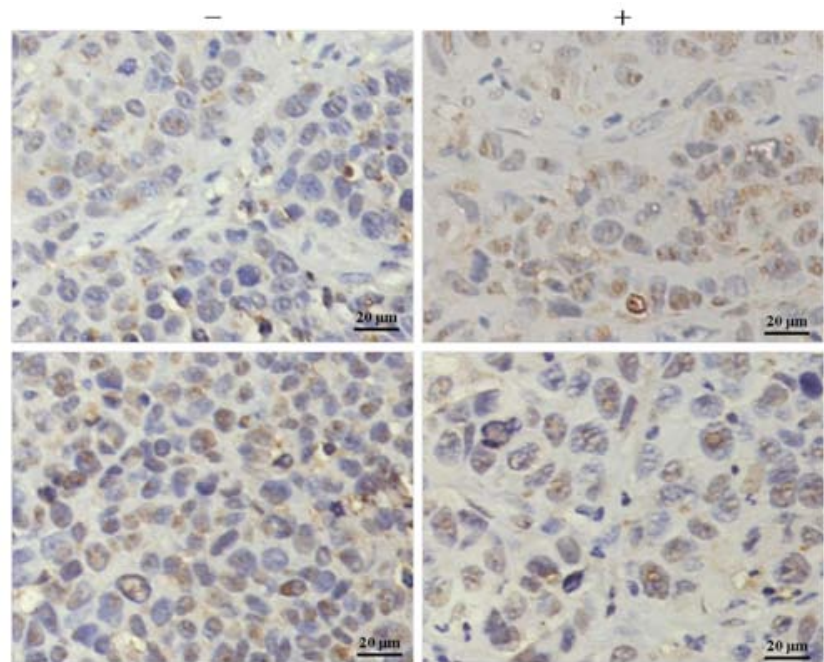

Eca-109/5-FU

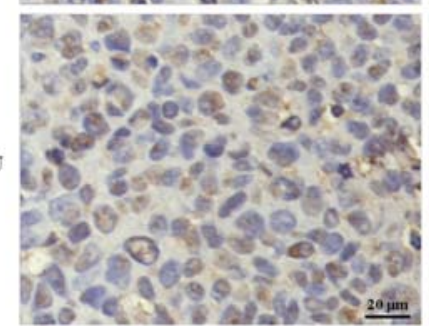

H

5-FU
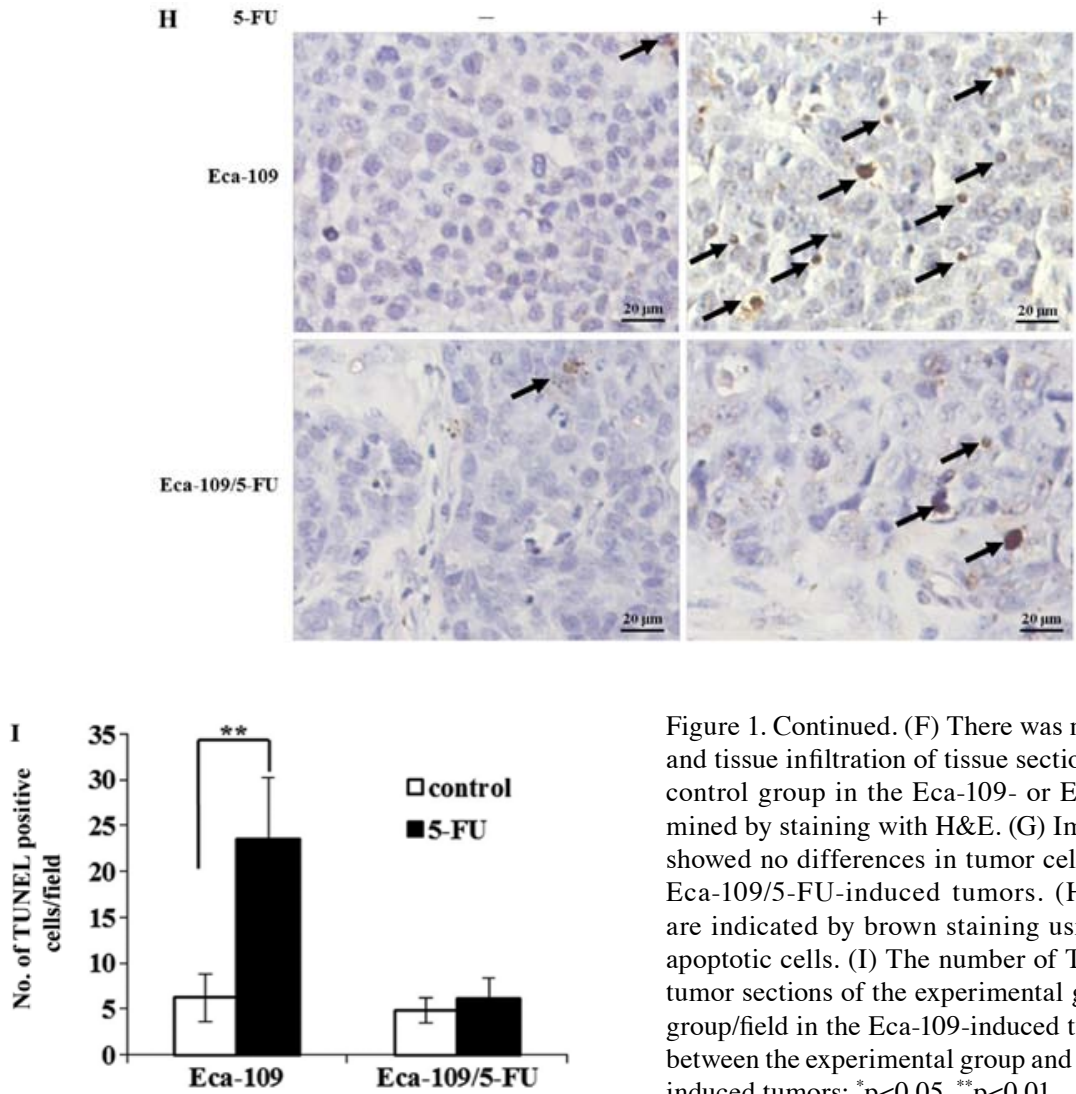

Figure 1. Continued. (F) There was no difference in tumor cell mitotic index and tissue infiltration of tissue sections between the experimental group and control group in the Eca-109- or Eca-109/5-FU-induced tumors as determined by staining with H\&E. (G) Immunohistochemical staining for PCNA showed no differences in tumor cell proliferative index in the Eca-109- or Eca-109/5-FU-induced tumors. (H) Tumor cells undergoing apoptosis are indicated by brown staining using the TUNEL method. Arrows show apoptotic cells. (I) The number of TUNEL-positive cells was higher in the tumor sections of the experimental group compared with that in the control group/field in the Eca-109-induced tumors, while no differences were found between the experimental group and control group/field in the Eca-109/5-FUinduced tumors; ${ }^{*} \mathrm{p}<0.05,{ }^{* * *} \mathrm{p}<0.01$. 

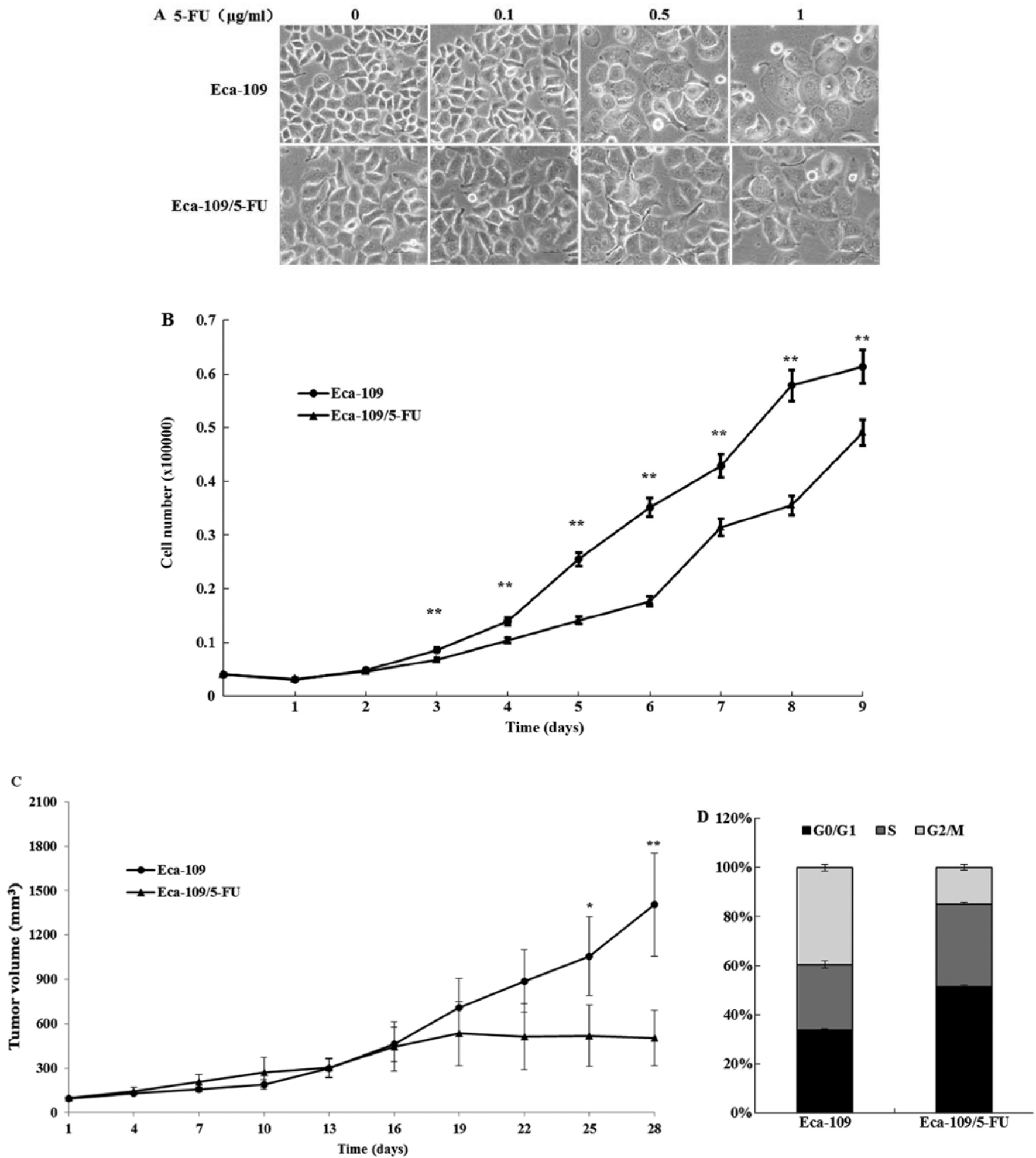

Figure 2. Proliferation of the 5-FU-resistant cell line Eca-109/5-FU was slower than that of Eca-109 in vitro and in vivo. (A) The effect of 5-FU on the cell morphology of Eca-109 and Eca-109/5-FU cells. Morphological characteristics were determined using an inverted microscope at an original magnification of $\mathrm{x} 200$. Cells were treated with different concentrations of 5-FU $(0,0.1$ and $1 \mu \mathrm{g} / \mathrm{ml})$ for 4 days, and then cells were observed using light microscopy. Eca109/5-FU cells exhibited a relatively larger cell size. (B) The cell growth curve of Eca-109/5-FU and Eca-109. The proliferation of the Eca-109 parental cells began to exceed Eca-109/5-FU cells at 2 days. (C) Growth changes of Eca-109/5-FU and Eca-109 xenograft tumors in vivo. When 5x10 ${ }^{6}$ cells were injected s.c. into the lower right flank of mice, the proliferation of Eca-109 cells became faster than Eca-109/5-FU after 16 days. (D) Cell cycle distribution of Eca-109/5-FU and Eca-109. Cells were cultured for 4 days, stained with PI and detected by FCM. Eca-109/5-FU cells exhibited G0/G1 and S phase arrest; "p<0.05, ${ }^{* *} \mathrm{p}<0.01$.

the cause of this result, the cell cycle distribution of Eca-109 and Eca-109/5-FU was determined by FCM. As shown in Fig. 2D, the percentages of Eca-109 and Eca-109/5-FU cells in the $\mathrm{G} 0 / \mathrm{G} 1, \mathrm{~S}$ and $\mathrm{G} 2 / \mathrm{M}$ phase were 33.72 and $51.45 \%, 26.68$ and $33.7 \%$, and 39.6 and $14.85 \%$, respectively. Compared with the parental cells (Eca-109), Eca-109/5-FU cells exhibited G0/G1 phase and S phase arrest with a concomitantly decreased cell percentage in the G2/M phase; the difference 

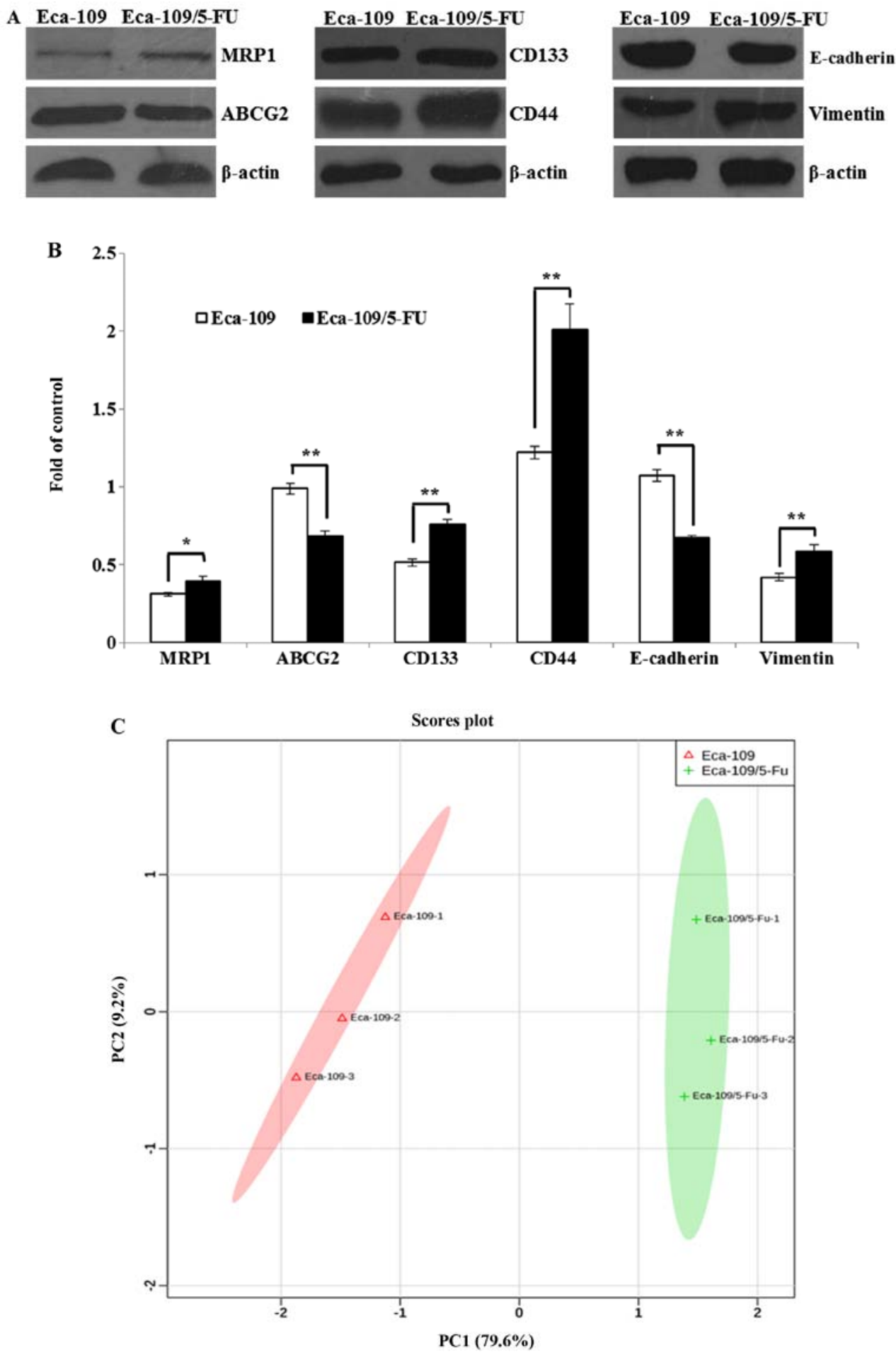

Figure 3. Significant drug resistance-related characteristics of Eca-109/5-FU cells. (A) Western blotting was used to determine drug resistance-related proteins from cell lysates. MRP1, vimentin, CD133 and CD44 were markedly increased and E-cadherin was decreased in the Eca-109/5-FU cells compared with the parental cell line Eca-109, while ABCG2 showed no obvious changes between them. (B) Protein expression levels of MRP1, ABCG2, CD133, CD44, vimentin and E-cadherin after normalization relative to $\beta$-actin. (C) Plot of PCA scores. ${ }^{*} \mathrm{p}<0.05,{ }^{* * *} \mathrm{p}<0.01$.

was significant at $\mathrm{p}<0.01$. The decreased cell percentage of the G2/M phase could be considered as an adverse factor in the proliferation of Eca-109/5-FU cells.

Significant drug resistance-related characteristics of Eca-109/5-FU. To determine the drug resistance mechanism of the Eca-109/5-FU cell line, western blotting was used to determine the expression level of various protein markers. Since the upregulation of $\mathrm{ABC}$ transporters in cancer cells is considered to be a primary determinant of the drug-resistant phenotype (37), we detected the expression levels of two main ABC transporters, MRP1 and ABCG2. The expression level of MRP1 was markedly increased in the Eca-109/5-FU cells relative to the parental cells (Eca-109), while ABCG2 showed 

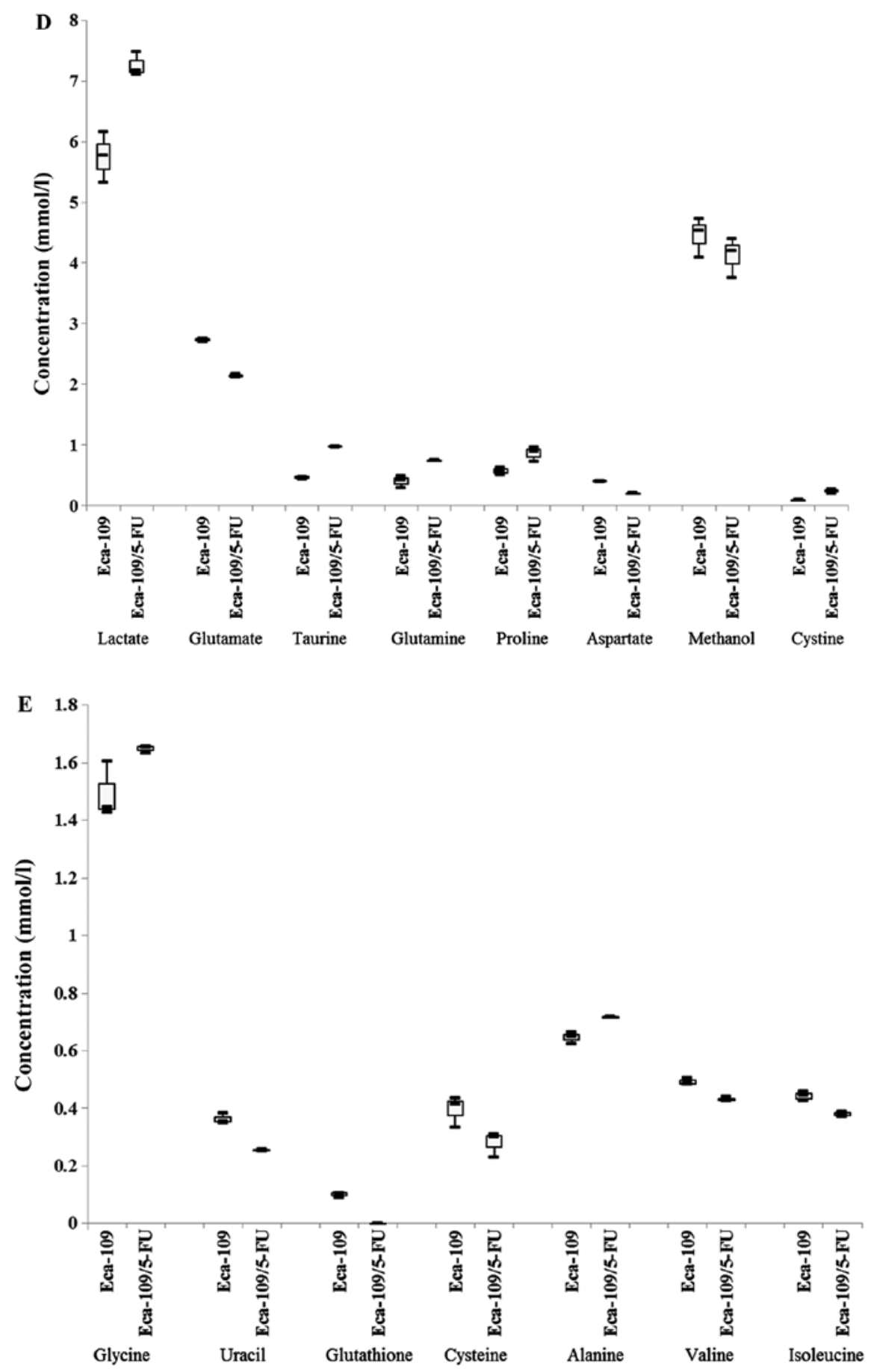

Figure 3. Continued. (D and E) Fifteen metabolites contributed to the differences in metabolism profile, and their concentrations were different between the Eca-109 and Eca-109/5-FU cells.

no obvious changes (Fig. 3A). However, the EMT-related marker vimentin was upregulated and another related marker E-cadherin was downregulated. The stem-like markers CD133 and CD44 were upregulated in the Eca-109/5-FU cells. These findings suggest that Eca-109/5-FU exhibited characteristics of EMT and CSCs, which contribute to drug resistance (Fig. 3A). To look for statistically significant differences, the MRP1/ $\beta$ actin, ABCG $2 / \beta$-actin, CD133/ $\beta$-actin, CD $44 / \beta$-actin, vimentin $/ \beta$-actin and $E$-cadherin $/ \beta$-actin ratios were calculated and a t-test was performed. The results confirmed that MRP1, CD133, CD44 and vimentin protein expression levels were markedly higher in the Eca-109/5-FU than levels in the Eca-109 cells, while E-cadherin and ABCG2 expression levels were lower than these in the parental cells $(p<0.05$, $\mathrm{p}<0.01)$ (Fig. 3B). Nuclear magnetic resonance (NMR) was used to determine differences in the contrast of the metabolic products between Eca-109/5-FU and Eca-109, and the analysis showed that the metabolite profiles between Eca-109/5-FU and Eca-109 were significantly different. This implied that the metabolism of 5-FU-resistant cells had changed, and this may be a characteristic of drug tolerance (Fig. 3C). Fifteen metabolites contributed to the difference in metabolite 
profiles: lactate, glutamate, taurine, glutamine, proline, aspartate, methanol, cystine, glycine, uracil, glutathione, cysteine, alanine, valine and isoleucine (Fig. 3D and E). Glutamine is a major source of carbon and energy for cancer cells; thus, glutaminolysis in cells is crucial for cancer cell metabolism (38). The metabolic tests showed that glutamate was reduced, while glutamine was significantly increased in the Eca-109/5-FU cells compared with the parental cells, and these changes suggested that Eca-109/5-FU cells have a stronger survival ability than parental cells.

\section{Discussion}

Chemotherapy is widely used in cancer treatment. As a classical chemotherapeutic drug, 5-fluorouracil (5-FU) can be utilized to treat ESCC (6). However, during treatment, ESCC cells often develop resistance to 5-FU, which leads to the failure of the therapy. To improve the disease prognosis in cancer patients, it is essential to overcome the resistance to cancer chemotherapy. The drug-resistant phenotype of cancer cells may be intrinsic or acquired after chemotherapy treatment using cytotoxic drugs (39). Establishing drug-resistant cancer cells through constant or intermittent drug stimulation has been an effective method for the investigation of drug resistance. Various 5-FU-resistant ESCC cell lines have been established and the mechanism of 5-FU resistance has been explored $(8,28)$. However, since Eca-109 is a relatively more chemotherapeutic sensitive ESCC cell line (32), it has not produced 5-FU-resistant cell lines, only CDDP-resistant cell lines (13) and paclitaxel-resistant cell lines (40). Therefore, we prepared 5-FU-resistant Eca-109/5-FU cells through stepwise exposure to increasing 5-FU concentrations. During the process of preparation, most Eca-109 cells were gradually enlarged with more vacuole formation when treated with low doses of 5-FU $(0.1 \mu \mathrm{g} / \mathrm{ml})$. Then, medium was removed and fresh medium without 5-FU was added for cell recovery. After one week, the surviving cells resumed exponential growth and the above treatment was repeated. Gradually, cells acquired tolerance to 5-FU and the RI reached 4.3. Notably, Eca-109/5FU's endurance capacity to CDDP also increased nearly 3 times compared with the parental cells. To date, the most common method for establishing resistant ESCC cell lines was an intermittent incremental induction method with various and inconsistent final dosages, such as $1.3(8), 10.4$ (28) and $5.2 \mu \mathrm{g} / \mathrm{ml}$ (29). However, Dinicola et al (41) reported that the final concentration of 5-FU could refer to the clinical plasma concentration of $2.0 \mu \mathrm{g} / \mathrm{ml}$. The other commonly used method is the pulse treatment method, which was described by Hummel et al (30) with a relatively low-dose of 5-FU $(0.65 \mu \mathrm{g} / \mathrm{ml})$. The resistant cells selected by the intermittent incremental method were more resistant than the cells selected by the pulse method (42).

Our experimental results indicated that the proliferation of Eca-109/5-FU cells was slower than Eca-109 cells in vitro and in vivo. The reason may be that Eca-109/5-FU cells exhibited G0/G1 phase and S phase arrest with a concomitantly decreased proportion of cells in the G2/M phase when compared with Eca-109 cells, which means that the number of proliferating cells decreased. There is a critical balance between cell cycle arrest (promoting DNA repair and survival) and cell death after chemotherapy. Various genes may be activated or inactivated in response to DNA damage to induce cell cycle arrest in the G1 phase, in which damaged DNA could be repaired (43). The slow proliferation and arrest of G0/G1 and S phase have also been found in other tumor cells resistant to 5-FU, such as 5-FU-resistant colorectal cancer cells HCT116-5FR, SW480-5FR (23) and HT29R (44); the 5-FU-resistant gastric cancer cells SGC-7901-FR (20) and SNU620/5-FU (45); the 5-FU-resistant liver cancer cells HLF-R2 and HLF-R10 (46). However, there was no significant difference in cellular proliferation between 5-FU-resistant oral squamous cancer cells $\mathrm{HSC} 2 / \mathrm{FU}$ and parental cells (25). The CDDP-resistant or paclitaxel-resistant Eca-109 cells also exhibited slow proliferation and arrest at the G0/G1 phase and $\mathrm{S}$ phase compared with Eca-109. The difference in proliferation implied that the underlying drug resistance-related mechanisms may be different, but all the changes contribute to cushioning the damage of cytotoxic drugs.

The ABC transporter family has always been a hotspot in the study of drug resistance mechanisms. Its powerful function increases drug efflux and decreases intracellular drug concentration, which eventually contributes to drug resistance. As a member of the ABC transporter family, MRP1 reduces the drug concentration in the nucleus by actively transporting drugs into subcellular organelles or indirectly affecting the distribution of drugs, which thereby avoids DNA injury. It can also form chloride ion channels or change channel activity to decrease the $\mathrm{pH}$ in the cytoplasm or organelles, which produces an acidic environment in which protonated drugs are largely discharged. However, MRP1 can move drugs out of cells through vesicle transportation or exocytosis (43). MRP1 is also upregulated in a variety of human malignancies, including different esophageal cancer cell lines or cancer tissues (47). It has been reported that the percentage of MRP1positive samples in esophageal cancer was significantly higher than that in gastric cancers and colorectal cancers, which implies that MRP1 may play a large role in the drug resistance in esophageal cancer (48). A number of clinical studies have observed correlations between high ABCG2 activity and the failure of a variety of cytotoxic and targeted therapies (49). High ABCG2 activity is also linked to a decreased clinical survival rate (50). Researchers have gradually assigned importance to the relationship between drug resistance and ABCG2. Our western blotting results indicated that the expression level of MRP1 was markedly increased in the Eca-109/5-FU cells relative to that noted in the parental Eca-109 cells, which indicates that Eca-109/5-FU has a stronger ability to pump out intracellular drugs, while ABCG2 showed significant downregulated in Eca-109/5-FU cells. Various studies have shown that the expression level of ABC transporters (MRP1 and $\mathrm{ABCG} 2$ ) in drug-resistant cancer cells exhibited no differences with parental cancer cells (42) and even lower levels (13). EMT is a prerequisite event for invasion in cancers, which plays a large role in 5-FU resistance (25). However, there are no studies of 5-FU-resistant ESCC. Our western blotting results indicated that the expression level of vimentin increased and that of E-cadherin decreased in the Eca-109/5-FU cells compared to these level in the Eca-109 cells. This means that EMT also occurs in 5-FU-resistant ESCC cells. EMT has also been associated with stem-like traits, such as self- 
renewal capacity, the expression of stemness markers and the formation of anchorage-independent spheres in several cancer models (44). Therefore, EMT is considered a key process for cancer stem cell generation (21). In addition, mechanisms of CSC resistance may also include the preferential activation of DNA damage checkpoints (51) and increasing drug exclusion by efflux pumps (52). CD133+ colon cancer cells have been confirmed to possess stem cell properties and have inherently higher resistance to 5-FU and oxaliplatin (53). As another stem cell marker, CD44 is used to identify CSCs in ESCC and $\mathrm{CD} 44^{+}$cells show more resistance to chemotherapy than the CD44-ESCC cells KYSE-30 (54). The upregulation of CD33 and CD44 in Eca-109/5-FU indicates that the acquired drug resistance may be connected to CSCs. The formation of EMT occurs together with metabolic alterations in various pathways, such as glycolysis and oxidative phosphorylation (55), and the reprogramming of metabolic pathways is one of the important mechanisms of chemoresistance (56). Sasada et al (33) showed that the 5-FU-resistant gastric cancer cell line MKN45/F2R exhibited significant changes in small molecule metabolism compared with parental cells. As the action time of 5-FU was prolonged, some of the concentrations of small molecules showed regular changes, such as gradual reductions in alanine, asparagine, valine, proline and citrulline; a gradual increase was also detected in parental cells when supplemented with 5-FU (33). Various studies confirmed that enhanced glutamine metabolism occurred in both patients and cell lines resistant to erlotinib (57). To further analyze the metabolic changes of 5-FU-resistant ESCC cells, we determined the metabolic products of Eca-109/5-FU and Eca-109 cells by NMR, and the metabolite profiles between the two were significantly different. Compared with the parental cell line Eca-109, the content of glutamine was significantly increased in the Eca-109/5-FU cells, while the content of glutamic acid was significantly reduced. Glutaminolysis and glutaminase (GLS) have been identified to be indispensable for the development and progression of cancer, including drug-resistant cancer cells (58). The high concentration of glutamine indicates a stronger reserved capacity for glutamine in Eca-109/5-FU cells relative to Eca-109 cells, and this phenomenon implies that Eca-109/5-FU may more easily adapt to the severe environment. The provision of energy is dependent on glycolysis in cancer cells, with greater production of lactate regardless of oxygen availability; this effect is called the Warburg effect (59). In our experience, there was a greater generation of lactate in the Eca-109/5-FU cells compared with that in the Eca-109 cells. This shows that the glycolytic pathway in Eca-109/5-FU cells is more active with more ATP acquired, and it is well known that the intracellular repair of cell structure and DNA and drug efflux through ABC transporters are all ATP-dependent.

The 5-FU-resistance mechanism in tumor cells is still unknown. There have been many attempts to increase cell sensitivity to chemotherapeutic agents. For example, curcumin mediates chemosensitization to 5-FU through the miRNAinduced suppression of EMT in chemoresistant SW480-5-FUR colorectal cancer cells (23), and tetrandrine (TET) can decrease the expression levels of MRP1 and MDR1 in 5-FU-resistant ESCC YES-2/DDP cells (37). Low-dose all-trans retinoic acid enhances the cytotoxicity of CDDP and 5-fluorouracil in CD $44^{+}$cancer stem cells (54); as a GLS inhibitor compound,
968 can reverse acquired erlotinib resistance in non-small cell lung cancer (58). RNAi-mediated EZH2 depletion (11), Annonaceous acetogenins (60) and astragaloside IV (61) could reverse the drug resistance of 5-FU-resistant liver cancer cells BEL-7402/5-FU by decreasing MRP1 and MDR1 expression. Hedyotis diffusa Willd overcomes 5-FU resistance in human colorectal cancer HCT-8/5-FU cells by downregulating the expression of MDR1 and ABCG2 (62). These results provided evidence of the screening of chemotherapy sensitizers for Eca-109/5-FU.

In conclusion, we established the 5-FU-resistant ESCC cell line Eca-109/5-FU by stepwise exposure to increasing $5-\mathrm{FU}$ concentrations in vitro and preliminarily identified its drug resistance mechanism. Eca-109/5-FU cells were resistant to 5-FU in vitro and in vivo and showed lower proliferation rates. These cells exhibit characteristics of EMT and CSCs. Higher intracellular concentrations of glutamine and lactate were detected, which implies that Eca-109/5-FU cells have a strong potential to survive when living in a severe environment. All of these results should contribute to further research using the drug-resistant Eca-109/5-FU cell line for selecting chemotherapy sensitizers.

\section{Acknowledgements}

The present study was supported by the Beijing Natural Science Foundation (grant no. 7142117) to Q.F. Ma and the National High Technology Research and Development Program of China (863 Program, grant no. 2014AA021605) to Z.L. Wang.

\section{References}

1. Torre LA, Bray F, Siegel RL, Ferlay J, Lortet-Tieulent J and Jemal A: Global cancer statistics, 2012. CA Cancer J Clin 65: 87-108, 2015.

2. Rustgi AK and El-Serag HB: Esophageal carcinoma. N Engl J Med 371: 2499-2509, 2014.

3. Stein HJ, Sendler A, Fink U and Siewert JR: Multidisciplinary approach to esophageal and gastric cancer. Surg Clin North Am 80: 659-686, 2000.

4. Copur S, Aiba K, Drake JC, Allegra CJ and Chu E: Thymidylate synthase gene amplification in human colon cancer cell lines resistant to 5-fluorouracil. Biochem Pharmacol 49: 1419-1426, 1995.

5. Scherf U, Ross DT, Waltham M, Smith LH, Lee JK, Tanabe L, Kohn KW, Reinhold WC, Myers TG, Andrews DT, et al: A gene expression database for the molecular pharmacology of cancer. Nat Genet 24: 236-244, 2000.

6. Denlinger CS, Ligibel JA, Are M, Baker KS, Broderick G, Demark-Wahnefried W, Friedman DL, Goldman M, Jones LW, King A, et al: NCCN Guidelines Insights: Survivorship, Version 1.2016. J Natl Compr Canc Netw 14: 715-724, 2016.

7. Inaba M, Mitsuhashi J, Sawada H, Miike N, Naoe Y, Daimon A, Koizumi K, Tsujimoto $\mathrm{H}$ and Fukushima M: Reduced activity of anabolizing enzymes in 5-fluorouracil-resistant human stomach cancer cells. Jpn J Cancer Res 87: 212-220, 1996.

8. Kikuchi O, Ohashi S, Nakai Y, Nakagawa S, Matsuoka K, Kobunai T, Takechi T, Amanuma Y, Yoshioka M, Ida T, et al: Novel 5-fluorouracil-resistant human esophageal squamous cell carcinoma cells with dihydropyrimidine dehydrogenase overexpression. Am J Cancer Res 5: 2431-2440, 2015.

9. Look KY, Moore DH, Sutton GP, Prajda N, Abonyi M and Weber G: Increased thymidine kinase and thymidylate synthase activities in human epithelial ovarian carcinoma. Anticancer Res 17: 2353-2356, 1997.

10. Nakamura A, Nakajima G, Okuyama R, Kuramochi H, Kondoh Y, Kanemura T, Takechi T, Yamamoto $M$ and Hayashi K: Enhancement of 5-fluorouracil-induced cytotoxicity by leucovorin in 5-fluorouracil-resistant gastric cancer cells with upregulated expression of thymidylate synthase. Gastric Cancer 17: 188-195, 2014. 
11. Tang B, Zhang Y, Liang R, Gao Z, Sun D and Wang L: RNAimediated EZH2 depletion decreases MDR1 expression and sensitizes multidrug-resistant hepatocellular carcinoma cells to chemotherapy. Oncol Rep 29: 1037-1042, 2013.

12. Cai B, Miao Y, Liu Y, Xu X, Guan S, Wu J and Liu Y: Nuclear multidrug-resistance related protein 1 contributes to multidrugresistance of mucoepidermoid carcinoma mainly via regulating multidrug-resistance protein 1: A human mucoepidermoid carcinoma cells model and Spearman's rank correlation analysis. PLoS One 8: e69611, 2013.

13. Wen J, Zheng B, Hu Y, Zhang X, Yang H, Luo KJ, Zhang X, Li YF and Fu JH: Establishment and biological analysis of the EC109/CDDP multidrug-resistant esophageal squamous cell carcinoma cell line. Oncol Rep 22: 65-71, 2009.

14. Yang AD, Fan F, Camp ER, van Buren G, Liu W, Somcio R, Gray MJ, Cheng H, Hoff PM and Ellis LM: Chronic oxaliplatin resistance induces epithelial-to-mesenchymal transition in colorectal cancer cell lines. Clin Cancer Res 12: 4147-4153, 2006.

15. Thiery JP: Epithelial-mesenchymal transitions in tumour progression. Nat Rev Cancer 2: 442-454, 2002.

16. Elliott BE, Hung WL, Boag AH and Tuck AB: The role of hepatocyte growth factor (scatter factor) in epithelial-mesenchymal transition and breast cancer. Can J Physiol Pharmacol 80: 91-102, 2002.

17. Elshamy WM and Duhé RJ: Overview: Cellular plasticity, cancer stem cells and metastasis. Cancer Lett 341: 2-8, 2013.

18. He K, Xu T and Goldkorn A: Cancer cells cyclically lose and regain drug-resistant highly tumorigenic features characteristic of a cancer stem-like phenotype. Mol Cancer Ther 10: 938-948, 2011.

19. Lloyd RV, Hardin H, Montemayor-Garcia C, Rotondo F, Syro LV, Horvath E and Kovacs K: Stem cells and cancer stem-like cells in endocrine tissues. Endocr Pathol 24: 1-10, 2013.

20. Xu ZY, Tang JN, Xie HX, Du YA, Huang L, Yu PF and Cheng XD: 5-Fluorouracil chemotherapy of gastric cancer generates residual cells with properties of cancer stem cells. Int J Biol Sci 11: 284-294, 2015.

21. Mani SA, Guo W, Liao MJ, Eaton EN, Ayyanan A, Zhou AY, Brooks M, Reinhard F, Zhang CC, Shipitsin M, et al: The epithelial-mesenchymal transition generates cells with properties of stem cells. Cell 133: 704-715, 2008

22. Chen S, Song X, Chen Z, Li X, Li M, Liu H and Li J: CD133 expression and the prognosis of colorectal cancer: A systematic review and meta-analysis. PLoS One 8: e56380, 2013.

23. Toden S, Okugawa Y, Jascur T, Wodarz D, Komarova NL, Buhrmann C, Shakibaei M, Boland CR and Goel A: Curcumin mediates chemosensitization to 5-fluorouracil through miRNAinduced suppression of epithelial-to-mesenchymal transition in chemoresistant colorectal cancer. Carcinogenesis 36: 355-367, 2015

24. Cheng L, Luo S, Jin C, Ma H, Zhou H and Jia L: FUT family mediates the multidrug resistance of human hepatocellular carcinoma via the PI3K/Akt signaling pathway. Cell Death Dis 4 : e923, 2013

25. Harada K, Ferdous T and Ueyama Y: Establishment of 5-fluorouracil-resistant oral squamous cell carcinoma cell lines with epithelial to mesenchymal transition changes. Int J Oncol 44 $1302-1308,2014$

26. Tanaka T, Bai T and Toujima S: Establishment and characterization of monoclonal 5-fluorouracil-resistant cell lines derived from human endometrial adenocarcinoma. Int J Oncol 37 : 731-736, 2010

27. Ohashi S, Kikuchi O, Tsurumaki M, Nakai Y, Kasai H, Horimatsu T, Miyamoto S, Shimizu A, Chiba T and Muto M: Preclinical validation of talaporfin sodium-mediated photodynamic therapy for esophageal squamous cell carcinoma. PLoS One 9: e103126, 2014.

28. Li B, Xu WW, Guan XY, Qin YR, Law S, Lee NP, Chan KT, Tam PY, Li YY, Chan KW, et al: Competitive binding between Id1 and E2F1 to Cdc20 regulates E2F1 degradation and thymidylate synthase expression to promote esophageal cancer chemoresistance. Clin Cancer Res 22: 1243-1255, 2016.

29. Li B, Tsao SW, Chan KW, Ludwig DL, Novosyadlyy R, Li YY, He QY and Cheung AL: Id1-induced IGF-II and its autocrine/endocrine promotion of esophageal cancer progression and chemoresistance - implications for IGF-II and IGF-IR-targeted therapy. Clin Cancer Res 20: 2651-2662, 2014

30. Hummel R, Sie C, Watson DI, Wang T, Ansar A, Michael MZ, Van der Hoek M, Haier J and Hussey DJ: MicroRNA signatures in chemotherapy resistant esophageal cancer cell lines. World J Gastroenterol 20: 14904-14912, 2014
31. Hummel R, Watson DI, Smith C, Kist J, Michael MZ, Haier J and Hussey DJ: Mir-148a improves response to chemotherapy in sensitive and resistant oesophageal adenocarcinoma and squamous cell carcinoma cells. J Gastrointest Surg 15: 429-438, 2011.

32. Shen LY, Wang H, Dong B, Yan WP, Lin Y, Shi Q and Chen KN: Possible prediction of the response of esophageal squamous cell carcinoma to neoadjuvant chemotherapy based on gene expression profiling. Oncotarget 7: 4531-4541, 2016.

33. Sasada S, Miyata Y, Tsutani Y, Tsuyama N, Masujima T, Hihara J and Okada M: Metabolomic analysis of dynamic response and drug resistance of gastric cancer cells to 5-fluorouracil. Oncol Rep 29: 925-931, 2013.

34. Weljie AM, Newton J, Mercier P, Carlson E and Slupsky CM: Targeted profiling: Quantitative analysis of $1 \mathrm{H}$ NMR metabolomics data. Anal Chem 78: 4430-4442, 2006.

35. Ouattara DA, Prot JM, Bunescu A, Dumas ME, Elena-Herrmann B, Leclerc E and Brochot C: Metabolomics-on-a-chip and metabolic flux analysis for label-free modeling of the internal metabolism of HepG2/C3A cells. Mol Biosyst 8: 1908-1920, 2012.

36. Ma Q, Jin B, Zhang Y, Shi Y, Zhang C, Luo D, Wang P, Duan C, Song H, Li X, et al: Secreted recombinant human IL-24 protein inhibits the proliferation of esophageal squamous cell carcinoma Eca-109 cells in vitro and in vivo. Oncol Rep 35: 2681-2690, 2016.

37. Wang TH, Wan JY, Gong X, Li HZ and Cheng Y: Tetrandrine enhances cytotoxicity of cisplatin in human drug-resistant esophageal squamous carcinoma cells by inhibition of multidrug resistance-associated protein 1. Oncol Rep 28: 1681-1686, 2012.

38. Moghanibashi M, Jazii FR, Soheili ZS, Zare M, Karkhane A, Parivar K and Mohamadynejad P: Proteomics of a new esophageal cancer cell line established from Persian patient. Gene 500: 124-133, 2012.

39. Baguley BC: Multidrug resistance in cancer. Methods Mol Biol 596: 1-14, 2010.

40. Wang C, Guo LB, Ma JY, Li YM and Liu HM: Establishment and characterization of a paclitaxel-resistant human esophageal carcinoma cell line. Int J Oncol 43: 1607-1617, 2013.

41. Dinicola S, Pasqualato A, Proietti S, Masiello MG, Palombo A Coluccia P, Canipari R, Catizone A, Ricci G, Harrath AH, et al: Paradoxical E-cadherin increase in 5FU-resistant colon cancer is unaffected during mesenchymal-epithelial reversion induced by $\gamma$-secretase inhibition. Life Sci 145: 174-183, 2016.

42. Yan XD, Li M, Yuan Y, Mao N and Pan LY: Biological comparison of ovarian cancer resistant cell lines to cisplatin and Taxol by two different administrations. Oncol Rep 17: 1163-1169, 2007.

43. Longley DB and Johnston PG: Molecular mechanisms of drug resistance. J Pathol 205: 275-292, 2005.

44. Denise C, Paoli P, Calvani M, Taddei ML, Giannoni E, Kopetz S, Kazmi SM, Pia MM, Pettazzoni P, Sacco E, et al: 5-Fluorouracil resistant colon cancer cells are addicted to OXPHOS to survive and enhance stem-like traits. Oncotarget 6: 41706-41721, 2015.

45. Kim NH,Kim SN, Oh JS, Lee S and Kim YK: Anti-mitotic potential of 7-diethylamino-3(2'-benzoxazolyl)-coumarin in 5-fluorouracilresistant human gastric cancer cell line SNU620/5-FU. Biochem Biophys Res Commun 418: 616-621, 2012.

46. Uchibori K, Kasamatsu A, Sunaga M, Yokota S, Sakurada T, Kobayashi E, Yoshikawa M, Uzawa K, Ueda S, Tanzawa $\mathrm{H}$, et al: Establishment and characterization of two 5-fluorouracil-resistant hepatocellular carcinoma cell lines. Int J Oncol 40: 1005-1010, 2012.

47. Langer R, Ott K, Feith M, Lordick F, Specht K, Becker K and Hofler H: High pretherapeutic thymidylate synthetase and MRP-1 protein levels are associated with nonresponse to neoadjuvant chemotherapy in oesophageal adenocarcinoma patients. J Surg Oncol 102: 503-508, 2010.

48. Takebayashi Y, Akiyama S, Natsugoe S, Hokita S, Niwa K, Kitazono M, Sumizawa T, Tani A, Furukawa T and Aikou T: The expression of multidrug resistance protein in human gastrointestinal tract carcinomas. Cancer 82: 661-666, 1998

49. Kim YK, Lee SS, Jeong SH, Ahn JS, Yang DH, Lee JJ, Shin MG and Kim HJ: $O C T-1, A B C B 1$, and $A B C G 2$ expression in imatinibresistant chronic myeloid leukemia treated with dasatinib or nilotinib. Chonnam Med J 50: 102-111, 2014

50. Benderra Z, Faussat AM, Sayada L, Perrot JY, Tang R, Chaoui D, Morjani H, Marzac C, Marie JP and Legrand O: MRP3, BCRP, and P-glycoprotein activities are prognostic factors in adult acute myeloid leukemia. Clin Cancer Res 11: 7764-7772, 2005.

51. Bao S, Wu Q, McLendon RE, Hao Y, Shi Q, Hjelmeland AB, Dewhirst MW, Bigner DD and Rich JN: Glioma stem cells promote radioresistance by preferential activation of the DNA damage response. Nature 444: 756-760, 2006. 
52. Ke CC, Liu RS, Yang AH, Liu CS, Chi CW, Tseng LM, Tsai YF, Ho JH, Lee CH and Lee OK: CD133-expressing thyroid cancer cells are undifferentiated, radioresistant and survive radioiodide therapy. Eur J Nucl Med Mol Imaging 40: 61-71, 2013.

53. Todaro M, Alea MP, Di Stefano AB, Cammareri P, Vermeulen L, Iovino F, Tripodo C, Russo A, Gulotta G, Medema JP, et al: Colon cancer stem cells dictate tumor growth and resist cell death by production of interleukin-4. Cell Stem Cell 1: 389-402, 2007.

54. Najafzadeh N, Mazani M, Abbasi A, Farassati F and Amani M: Low-dose all-trans retinoic acid enhances cytotoxicity of cisplatin and 5-fluorouracil on CD44 ${ }^{+}$cancer stem cells. Biomed Pharmacother 74: 243-251, 2015.

55. Thomson S, Petti F, Sujka-Kwok I, Mercado P, Bean J, Monaghan M, Seymour SL, Argast GM, Epstein DM and Haley JD: A systems view of epithelial-mesenchymal transition signaling states. Clin Exp Metastasis 28: 137-155, 2011.

56. Cioce M, Valerio M, Casadei L, Pulito C, Sacconi A, Mori F, Biagioni F, Manetti C, Muti P, Strano S, et al: Metformin-induced metabolic reprogramming of chemoresistant ALDH ${ }^{\text {bright }}$ breast cancer cells. Oncotarget 5: 4129-4143, 2014.

57. Makinoshima H, Takita M, Matsumoto S, Yagishita A, Owada S, Esumi H and Tsuchihara K: Epidermal growth factor receptor (EGFR) signaling regulates global metabolic pathways in EGFR-mutated lung adenocarcinoma. J Biol Chem 289: 20813-20823, 2014.
58. Xie C, Jin J, Bao X, Zhan WH, Han TY, Gan M, Zhang C and Wang $\mathrm{J}$ : Inhibition of mitochondrial glutaminase activity reverses acquired erlotinib resistance in non-small cell lung cancer. Oncotarget 7: 610-621, 2016.

59. Warburg O: On the origin of cancer cells. Science 123: 309-314, 1956.

60. Qian JQ, Sun P, Pan ZY and Fang ZZ: Annonaceous acetogenins reverses drug resistance of human hepatocellular carcinoma BEL-7402/5-FU and HepG2/ADM cell lines. Int J Clin Exp Pathol 8: 11934-11944, 2015.

61. Wang PP, Xu DJ, Huang C, Wang WP and Xu WK: Astragaloside IV reduces the expression level of P-glycoprotein in multidrug-resistant human hepatic cancer cell lines. Mol Med Rep 9: 2131-2137, 2014

62. Li Q, Wang X, Shen A, Zhang Y, Chen Y, Sferra TJ, Lin J and Peng J: Hedyotis diffusa Willd overcomes 5-fluorouracil resistance in human colorectal cancer HCT-8/5-FU cells by downregulating the expression of P-glycoprotein and ATP-binding casette subfamily G member 2. Exp Ther Med 10: 1845-1850, 2015 